\title{
Kemampuan Menulis Feature Human Interest Berbasis Kontekstual Mahasiswa STKIP PGRI Lubuklinggau
}

\author{
${ }^{1}$ Sri Murti*, ${ }^{2}$ Dian Ramadan Lazuardi \\ STKIP PGRI Lubuklinggau ${ }^{1,2}$ \\ srimurti05@gmail.com
}

\author{
Pengiriman: 08/11/2020; Diterima: 12/11/2020; Publikasi: 23/11/2020 \\ DOI: $10.31629 /$ jermal.v1i2.2737
}

\begin{abstract}
Abstrak
Penelitian ini bertujuan untuk mendeskripsikan kemampuan menulis feature Human Interest berbasis kontekstual pada Mahasiswa STKIP PGRI Lubuklinggau. Penelitian ini menggunakan metode deskriptif. Sumber data dalam penelitian ini adalah naskah feature yang ditulis oleh mahasiswa yang mengambil mata kuliah Jurnalistik sebanyak 15 Mahasiswa. Teknik pengumpulan data yang digunakan dalam penelitian ini adalah teknik dokumentasi, teknik pengamatan, teknik pustaka, dan teknik catat. Berdasarkan tabel nilai ketepatan struktur, nilai rata-rata yang diperoleh sebesar 60 yang berada pada kategori Cukup (C). Struktur tulisan feature ada 5 di antaranya Head (Judul) sebesar 12,5\%, Lead (Intro, kalimat pembuka) sebesar 68,75\%, Bridge (penghubung antara lead dan isi tulisan) sebesr 50\%, Body (isi tulisan) sebesar 100\%, dan Ending (Penutup tulisan) sebesar 75\%. Adapun temuan pilihan kata yang digunakan dalam feature yaitu kata ilmiah, kata populer, dan idiom. Sementara itu, hasil perolehan nilai rata-rata terhadap kualitas ejaan dan tata tulis yaitu sebesar 68,31 dengan kategori Cukup (C). Feature yang dibuat mengandung unsur Human Interest yang menjadikan pembaca ikut merasakan apa yang mereka gambarkan dalam tulisannya. Beberapa unsur human interest terkait dengan rasa tanggung jawab terhadap masa depan, rasa tanggung jawab untuk membahagiakan orang tua, dan rasa tanggung jawab yang lain. Unsur human interest menjadi daya tarik tersendiri bagi pembaca dalam membaca sebuah feature. Adapun simpulan yang didapat berdasarkan hasil penelitian adalah rendahnya kemampuan menulis feature Human Interest berbasis kontekstual pada mahasiswa STKIP PGRI Lubuklinggau.

Kata Kunci : feature, human interest, kemampuan menulis, kontekstual.
\end{abstract}

\begin{abstract}
This research aims to describe the ability to write Human Interest features based on contextual for STKIP PGRI Lubuklinggau collage. This research uses a descriptive method. The data source in this research was a feature script written by 15 students who took Journalism courses. Data collecti techniques used in this research are documentation, observation, library techniques, and note techniques. Based on the table of structural accuracy values, the average value obtained is 60 which is in the Enough category $(\mathrm{C})$. There are 5 structure of feature writing, including Head (Title) of 12.5\%, Lead (Intro, opening sentence) of 68.75\%, Bridge (liaison between the lead and the content of the writing) by $50 \%$, Body (writing content) by $100 \%$, and Ending (closing writing) by $75 \%$. The findings of word choices used in features are scientific words, popular words, and idioms. Meanwhile, the average score for the quality of spelling and writing is 68.31 in the enough category $(\mathrm{C})$. The feature that is made contains elements of Human Interest which makes readers feel what they are describing in their feature writing. Several elements of human interest are related to a sense of responsibility for the future, a sense of responsibility to make parents happy, and other feelings of responsibility. The human interest element becomes the main attraction for readers in reading a feature. The conclusion obtained based on the research results is the low ability to write Human Interest features based on contextual for STKIP PGRI Lubuklinggau students.
\end{abstract}

Key Words : Feature, human interest, ability writing, contextual.

\section{PENDAHULUAN}

Keberadaan jurnalistik sebagai ilmu tidak dapat dilepaskan dari aktivitas komunikasi. Pada era milenium global seperti sekarang, jurnalistik dipandang sebagai salah satu elemen yang memiliki kekuatan komunikasi. Efek jurnalistik tidak hanya luas, tetapi juga selalu up to date. Menurut Yunus (2010: 1) menyebutkan bahwa sejatinya, jurnalistik dan komunikasi seperti dua sisi mata uang. Keduanya dapat menjadikan masyarakat lebih mudah dalam memperoleh informasi. Jurnalistik dan komunikasi memiliki peran 
yang sama penting. Terkadang sebagian kalangan menempatkan jurnalistik menjadi bagian komunikasi, namun secara subtansial, jurnalistik dan komunikasi memiliki kesetaraan.

Tidak dapat dipungkiri, sejak era reformasi bergulir jurnalistik mengalami perkembangan yang pesat. Pasca reformasi melanda, jurnalistik telah mencapai puncak kebebasan. Bebas dalam menyajikan berita dalam bentuk apapun. Di era reformasi ini pun, jurnalistik berkembang pesat baik segi jumlah media yang ahdir, sumber daya manusia yang terlibat, maupun pengaruhnya terhadap masyarakat sebagai audien.

Jurnalistik itu sendiri merupakan kegiatan menghimpun berita, mencari fakta, dan melaporkan sebuah peristiwa. Jurnalistik sangat penting di mana pun dan kapan pun. Sebuah negara yang demokratis, sangat membutuhkan kegiatan jurnalistik ini. Tidak peduli apapun perubahan-perubahan yang terjadi di masa depan baik sosial, ekonomi, politik maupun yang lainnya. Keperluan untuk mengetahui apa yang terjadi merupakan sejarah lahirnya jurnalisme. Sependapat dengan pernyataan (Romli, 2020:15) yang menyatakan bahwa jurnalistik dipahami sebagai proses peliputan, penulisan, dan penyebarluasan informasi (aktual) atau berita melalui media massa. Secara ringkas dan praktis, jurnalistik bisa diartikan sebagi memberitakan sebuah peristiwa.

Dalam masyarakat modern, kegiatan jurnalistik menjadi kegiatan yang tidak asing lagi. Terlebih pada zaman saat ini, teknologi informasi memainkan peranan yang sangat penting. Kemunculan teknologi informasi inilah yang menajdi latar belakang kemajuan jurnalistik. Jurnalistik sendiri terbagi menjadi dua yaitu jurnalistik kovensional dan jurnalistik online. Jurnalistik on line sendiri merupakan generasi baru setelah jurnalistik konvensional (media cetak) dan jurnalistik penyiaran.

Mengingat jurnalistik sudah berkembang dengan sangat cepat, maka salah satu bentuk perkembangannya adalah dengan menjadikan jurnalistik sebagai disiplin ilmu. Di perguruan tinggi, jurnalistik bahkan selain menjadi jurusan, juga menjadi mata kuliah pilihan yang menjadi wadah bagi mahasiswa yang berminat untuk mempelajari bidang jurnalistik. Salah satunya adalah menjadi mata kuliah wajib di program studi pendidikan bahasa dan sastra Indonesia STKIP PGRI Lubuklinggau. Sebagai mata kuliah pilihan, tentunya jurnalistik sendiri memiliki tujuan untuk menambah pengetahuan yang memadai hal-hal tentang jurnalistik serta mampu bersikap positif terhadap profesi jurnalistik yang ada di Indonesia.

Salah satu hal yang dipelajari dalam mata kuliah Jurnalistik adalah menulis berita Feature. Berita feature sendiri merupakan sebuah berita yang berbentuk karangan dengan memiliki syarat-syarat tertentu. Menurut pendapat Sumadiria (2017:150) mengatakan bahwa feature adalah cerita atau karangan khas yang berpijak pada fakta atau data yang diperoleh melalui proses jurnalistik. Melihat pengertian feature tersebut maka kedudukan feature dalam media massa sangat penting. Posisi dan eksistensinya tidak tergantikan oleh produk jurnalistik yang lain. Tidak oleh berita langsung, artikel ataupun tajuk rencana, bahkan tidak pula oleh pokok dan karikatur. Setiap informasi dikelola secara profesional serta memiliki kredibilitas yang tinggi sehingga memberi tempat tersendiri di hati masyarakat terutama pembaca. Feature menjadi salah satu bentuk karya jurnalistik sastra tidak hanya untuk memenuhi aspek kesemestaan media massa semata. Lebih dari itu feature sekaligus juga diharapkan dapat meningkatkan citra media di mata khalayak.

Tidak hanya sebagai sebuah berita, feature sendiri adalah tulisan yang menarik dan mengandung unsur faktual dan human touch (sentuhan perasaan manusia). Artinya berita tersebut diolah sedemikian rupa, sehingga letak kelayakannya untuk 
dimuat dalam media bukan berita itu penting, melainkan karena berita itu ditulis secara menarik atau memang sedang tidak menarik. Feature itu sendiri bertujuan untuk menghibur, menimbulkan rasa heran, geli, takjub, cemas, terharu, kasihan, jengkel, atau sekedar untuk mendidik dan menambah pengetahuan bagi si pembaca.

Untuk membuat sebuah feature yang layak dibaca tentunya harus mengikuti syarat-syarat tertentu, di antaranya memenuhi struktur tulisan, gaya bahasa, ejaan, dan unsur linguistik lainnya. Fokus pada isi tertentu dari sebuah peristiwa dan menonjolkan biasanya dari segi human interest yang membangkitkan emosi mengundang simpati, empati, dan kesedihan atau bahkan amarah. Istilah human interest sulit diterjemahkan dengan tepat ke dalam bahasa Indonesia tanpa mengurangi sebagian maknanya, tetapi menurut MacDougall ( dalam Kusumaningrat, 2016: 224) interest atau perhatian pada manusia dan peristiwaperistiwa karena manusia serta peristiwaperistiwa tersebut menyangkut pria dan wanita yang berada pada situasi yang bisa saja dialami oleh setiap orang, disebut human interest. Bisa disebut human ineterest jika terdapat perhatian pada kesejahteraan atau kehisupan orang lain.

Salah satu bentuk bentuk yang mengandung human ineterest adalah feature biografi yang berisikan kejadian menarik, lucu, menggelikan atau mengharukan yang dialami seseorang. Dalam penelitian ini, penulis mengumpulkan data berbentuk hasil tulisan feature mahasiswa yang mengambil mata kuliah Jurnalistik. Dengan data yang diperoleh, maka penulis akan melihat kemampuan menulis naskah feature dari naskah yang sudah dibuatnya berdasarkan kelengkapan struktur tulisan, penggunaan diksi, dan ejaan. Fokus penelitian tidak hanya pada kelengkapan struktur melainkan penggunaan diksi yang menentukan keberhasilan sebuah feature. Sejalan dengan pendapat Keraf (2009: 87) persoalan ketepatan pilihan kata akan menyangkut pula masalah makna kata dan kosakata seseorang.

Berdasarkan latar belakang di atas maka penulis melakukan penelitian dengan judul "Kemampuan Menulis Naskah Feature Human Interest Berbasis Kontekstual pada Mahasiswa STKIP PGRI Lubuklinggau". Adapun penelitian serupa pernah dilakukan oleh Lazuardi (2017) dengan judul penelitian "Analisis Berita Feature Mahasiswa Semester V Prodi Pendidikan Bahasa dan Sastra Indonesia STKIP PGRI Lubuklinggau”. Hasil penelitian menjelaskan tentang struktur tulisan yang terdapat di dalam tulisan feature yang dibuat, sedangkan penelitian yang akan dilakukan oleh penulis melihat kemampuan menulis feature dengan menilai struktur tulisan dan ketepatan pilihan kata. Sementara persamaannya adalah sama-sama menjadikan melakukan penelitian di tempat yang sama yaitu STKIP PGRI Lubuklinggau.

\section{METODE PENELITIAN}

Penelitian ini menggunakan metode deskriptif. Melalui metode deskriptif penulis akan mendeskripsikan data-data yang diperoleh dari hasil penelitian dan mengumpulkan informasi mengenai status suatu gejala yang ada, yaitu keadaan gejala menurut apa adanya pada saat penelitian dilakukan. Penelitian ini langsung meneliti, mempelajari, menganalisis, menafsirkan, dan menarik kesimpulan dari data yang diperoleh. Selain itu, sebuah penelitian sangat berkaitan erat dengan sumber data. Sumber data dalam penelitian ini adalah naskah feature yang ditulis oleh mahasiswa yang mengambil mata kuliah Jurnalistik sebanyak 15 Mahasiswa. Teknik pengumpulan data yang digunakan dalam penelitian ini adalah teknik dokumentasi yaitu mencari data mengenai hal atau variabel yang berupa catatan, transkrip, buku, surat kabar, majalah, prasasti, notulen rapat, agenda, dan sebagainya. Dalam penelitian ini penulis mendokumentasikan hasil naskah feature 
mahasiswa, kemudian menggunakan teknik pengamatan, teknik pustaka, dan teknik catat.

Adapun langkah-langkah teknik analisis data yang dilakukan penulis sebagai berikut: (1) Membaca naskah feature yang ditulis oleh mahasiswa; (2) Menandai struktur tulisan feature pada naskah yang ditulis; (3) Menghitung masing-masing struktur tulisan, pilihan kata dan ejaan pada feature yang ditemukan; (4) Menentukan unsur human interest; (5) Menginterpretasi hasil analisis data secara menyeluruh.

\section{HASIL PENELITIAN DAN PEMBAHASAN}

\section{Hasil Penelitian}

Berdasarkan hasil penelitian yang dilakukan penulis berkaitan dengan judul Kemampuan Menulis Feature Human Interest Berbasis Kontekstual pada Mahasiswa STKIP PGRI Lubuklinggau, maka diperoleh data sebagai berikut:

\section{Kemampuan Menulis Naskah Feature Mahasiswa STKIP $\quad$ PGRI Lubuklinggau.}

\section{a. Penguasaan Struktur}

Untuk melihat kemampuan menulis naskah feature mahasiswa STKIP PGRI Lubuklinggau, penulis melihat dari segi struktur tulisan feature. Berdasarkan hasil data diperoleh nilai ketepatan struktur dalam naskah feature yang ditulis mahasiswa STKIP PGRI Lubuklinggau, adalah sebagai berikut.

Tabel 1

Penguasaan Struktur

\begin{tabular}{cccc}
\hline $\begin{array}{c}\text { Jumlah } \\
\text { Mahasiswa }\end{array}$ & $\begin{array}{c}\text { Total } \\
\text { Skor }\end{array}$ & $\begin{array}{c}\text { Nilai } \\
\text { Rata- } \\
\text { rata }\end{array}$ & Kategori \\
\hline 16 & 960 & 60 & Cukup ( C ) \\
\hline
\end{tabular}

Berdasarkan tabel nilai ketepatan struktur, maka nilai rata-rata yang diperoleh sebesar 60 yang berada pada kategori Cukup (C). Struktur tulisan feature menurut (Romli, 2020:84) ada 5 diantaranya Head (Judul), Lead (Intro, kalimat pembuka), Bridge (penghubung antara lead dan isi tulisan), Body (isi tulisan), dan Ending (Penutup tulisan). Maka dari 15 naskah yang sudah diteliti ditemukan data sebagai berikut.

Tabel 2

Penguasaan Struktur

\begin{tabular}{ccccc}
\hline Head & Lead & Bridge & Body & Ending \\
\hline 2 & 11 & 8 & 16 & 12 \\
$12,5 \%$ & $68,75 \%$ & $50 \%$ & $100 \%$ & $75 \%$ \\
\hline
\end{tabular}

Dari tabel tersebut, dapat disimpulkan bahwa pada naskah feature yang ditulis oleh mahasiswa STKIP PGRI Lubuklinggau secara keseluruhan tidak memiliki struktur yang lengkap. Terlihat dari beberapa naskah yang dibuat hanya 2 naskah yang memiliki Head (Judul ) yaitu naskah 08 dengan judul "Keinginan dan Impianku" dan naskah 12 dengan judul "Impianku". Selanjutnya, jika dilihat dari jumlah naskah yang memiliki Lead (intro, kalimat pembuka) sebanyak 11 naskah, dan 5 naskah lainnya tidak memiliki Lead. Terdapat 8 naskah yang memiliki Bridge dalam tulisan feature nya. Bridge disini adalah penghubung antara pembuka dengan isi feature.

Selain itu, dari 16 naskah feature yang ada, 16 naskah tersebut memiliki Body (isi tulisan), dan terakhir dilihat dari ending (penutup) penulis menemukan 12 naskah yang memiliki Ending atau penutup tulisan. Rata-rata naskah feature yang dibuat berisikan tentang perjalanan hidup mahasiswa dengan menuliskan riwayat pendidikan mereka. Diawali dari mereka lahir hingga menempuh pendidikan di bangku perguruan tinggi. Namun, jika dilihat dari judul, hanya 2 naskah yang memiliki judul yaitu naskah 08 dan naskah 12. Empat belas naskah lainnya tidak memasukkan judul di dalam naskah. Penyebab tidak memasukkan judul adalah faktor fokus pada bagian struktur lainnya, padahal judul merupakan bagian penting dalam sebuah karangan termasuk naskah feature. 
Pada bagian Lead atau pembuka feature, 11 naskah memiliki lead sedangkan 5 naskah lainnya tidak memiliki Lead atau bagian pembuka di antaranya naskah 01,02,03, 07, dan 13. Dari kelima naskah yang tidak memiliki bagian Lead, rata-rata langsung masuk ke bagian inti atau isi cerita. Adapun contoh Lead dalam naskah seperti pada kutipan berikut " $A k u$ terlahir dari keluarga sangat sederhana. Ayahku seorang petani sawit, sedangkan ibuku adalah seorang ibu rumah tangga. Kami menganut agama islam, tetapi kakek dan nenekku dari pihak ibu mneganut agama kristen" (Naskah 04). Lead berfungsi sebagai kunci utama dalam tulisan feature. Rata-rata lead yang digunakan dalam naskah feature mahasiswa STKIP PGRI Lubuklinggau berupa Lead deskriptif. Namun, ada juga yang menggunakan Lead dalam bentuk lain yaitu Lead bercerita, seperti pada kutipan berikut: "Setiap manusia memiliki keyakinan dan kemampuan untuk melaksanakan impian-impian yang sudah dia rencanakan sejak jauh hari. Impian orang berkembang seiring kebutuhan dan realitas dihadapi” (Naskah 08 ).

Struktur tulisan berikutnya adalah Bridge yang berfungsi sebagai penghubung antara Lead dan isi tulisan. Dari hasil data yang diperoleh hanya 8 naskah yang memiliki bagian Bridge ini. Adapun contoh Bridge dalam naskah seperti pada kutipan berikut: "Setelah saya bersekolah di SD 53 di waktu itu saya cukup memiliki prestasi yang baik, baik di akademi maupun ekstra" (Naskah 03). Selain itu, kutipan maskah yang memiliki Bridge sebagai berikut: "Banyak pengalaman yang saya gali, mulai dari teman-teman yang asyik dan ramah, tertawa bersama sampai kadang kala terlelap dalam gelapnya malam sangking asyiknya bermain" (Naskah 11). Tujuan dari bridge sendiri adalah menjadi bagian pelengkap yang menghubungkan antara bagian pembuka ke bagian isi. Karena feature yang baik adalah feature yang tidak langsung ke bagian inti melainkan ada bagian tulisan yang menjadi daya tarik sebelum masuk ke bagian inti tulisan feature.

Selanjutnya adalah bagian isi tulisan atau disebut dengan Body. Pada bagian Body, menjadi bagian inti cerita dalam sebuah feature. Ditemukan 15 Body dalam 15 naskah feature yang ada. Adapun contoh bagian Body dalam naskkah feature seperti pada kutipan berikut:" Saat umur 17 tahun aku sudah memutuskan untuk merantau ikut kakak ku tinggal di Lubuklinggau yang mungkin teman seusiaku saat itu masih bersama dnegan orang tuanya di rumah" (Naskah 01). Kutipan berikutnya yang menjelaskan tentang Body, seperti pada kutipan berikut: " Niatku untuk membahagiakan kedua orang tuaku tak pernah surut, tak pernah lepas dari ingatanku. Apapun akan ku berikan demi membuat mereka bahagia" (Naskah 09). Pada bagian Body berisikan tentang bahasan dari tema dengan cara meleburkan bentuk, gaya dan teknik penulisan yang khas pada setiap penulis. Pada bagian Body tentunya memperhatikan bentuk kesatuan, hubungan dan penekanan dengan tujuan untuk menyampaikan tema cerita.

Terakhir pada bagian Ending atau penutup cerita. Adapun contoh kutipan pada bagian ini sebagai berikut: "Semoga langkahku ke depan dipermudah citacitaku untuk merubah nasib tercapai"'(Naskah 15). Kutipan Ending berikutnya seperti pada kutipan berikut:" Alhamdulillah, tuhan memberikan jalan bagi yang berusaha, semua keluhan saya terjawab setelah melanjutkan kuliah dan sekarang tahun 2020 saya menginjak ke semester 5 dimana wisuda dan studi saya akan segera selesai dan saya persembahkan semuanya kepada orang tua saya tercinta" (Naskah 04). Tujuan dari bagian Ending ini adalah menimbulkan kesan mendalam dan kuat di benak pembaca serta menumbuhkan hasrat pembaca untuk terus memakai gagasan yang dapat dipahami.

\section{Pilihan Kata dan Ejaan}


Selain struktur tulisan, pendayaangunaan kata dan kesesuaian pilihan kata menjadi penentu keberhasilan dalam sebuah tulisan feature. Artinya bahwa ketepatan dan kecocokan kata yang akan digunakan berupa perbedaan tata bahasa, pola kalimat, dan beberapa segi linguistik lainnya. Adapun temuan pilihan kata dan kesesuaian pilihan kata dalam naskah feature yang ditulis oleh mahasiswa STKIP PGRI Lubuklinggau sebagai berikut.

\begin{tabular}{clrr}
\hline No & Jenis Diksi & Jumlah & Persentase \\
\hline 1 & Kata Ilmiah & 10 & 62.5 \\
2 & Kata Populer & 9 & 56.25 \\
3 & Idiom & 8 & 50 \\
\hline
\end{tabular}

Sementara itu, berdasarkan hasil penilaian terhadap kualitas ejaan dan tata tulis maka diperoleh nilai rata-rata sebagai berikut

\begin{tabular}{ccc}
\hline $\begin{array}{c}\text { Jumlah } \\
\text { Nilai }\end{array}$ & Rata-Rata & Kategori \\
\hline 1093 & 68.3125 & Cukup (C)
\end{tabular}

Berdasarkan tabel di atas, maka nilai ratarata berkenaan dengan kualitas ejaan dan tata tulis berada pada kategori Cukup (C). Hal ini menandakan bahwa kemampuan penguasaan ejaan masih rendah.

\section{Unsur Human Interest Naskah Feature Mahasiswa STKIP $\quad$ PGRI Lubuklinggau.}

Istilah Human interest sulit diterjemahkan ke dalam bahasa Indonesia dengan tepat, namun fokus dari human interest adalah perhatian pada manusia, dan pada peristiwa-peristiwa karena manusia serta peristiwa-peristiwa menyangkut priawanita yang berada di dalam situasi yang bisa saja dialami oleh setiap orang. Berdasarkan hasil pengamatan terhadap feature yang ditulis mahasiswa, secara keseluruhan mengandung unsur human interest yang berfokus pada kehidupan pribadi dan bahkan perjuangan dalam menghadapi peristiwa di dalam kehidupan. Feature yang dibuat, rata-rata menimbulkan rasa simpati dan empati bagi penulis sebagai pembaca naskah feature yang ditulis mahasiswa STKIP PGRI Lubuklinggau. Adapun bukti kutipan naskah yang mengandung unsur feature seperti pada beberapa kutipan berikut:

"Aku terlahir dari keluarga sederhana, ibu bapakku hanya seorang petani karet dan meskipun hidup dalam kesederhanaan aku dan saudaraku sangat bersyukur menjadi bagian dari keluarga ini" (Naskah 01)

"Di sinilah Saya merasakan hidup yang sebenarnya, kerasnya kehidupan kota, pahit manisnya sudah saya alami" (Naskah 05)

"Sejak kecil, aku sering ditinggal oleh ayahku untuk bekerja, bahkan sampai 2 minggu aku tak berjumpa dengan beliau karena beliau pergi ke berbagai kota" (Naskah 09)

Dari beberapa kutipan di atas menunjukkan bahwa feature yang dibuat mengandung unsur Human Interest yang menjadikan pembaca ikut merasakan apa yang mereka gambarkan dalam tulisan feature nya. Beberapa unsur Human Interest terkait dengan rasa tanggung jawab terhadap masa depan, rasa tanggung jawab untuk membahagiakan orang tua, dan rasa tanggung jawab yang lain. Unsur Human Interest menjadi daya tarik tersendiri bagi pembaca dalam membaca sebuah feature.

\section{PEMBAHASAN}

Berdasarkan hasil data nilai terkait struktur tulisan feature diperoleh nilai rata-rata sebesar 60 yang berada pada kategori Cukup (C). Hal ini menandakan bahwa kemampuan memahami struktur dalam berita feature masih rendah. Banyak 
tulisan feature yang dibuat justru tidak memiliki kelengkapan unsur secara utuh. Bahkan dari 16 naskah feature yang ada, hanya 2 naskah yang memiliki struktur yang lengkap. Struktur tulisan feature menurut (Romli, 2020:84) ada 5 di antaranya Head (Judul), Lead (Intro, kalimat pembuka), Bridge (penghubung antara lead dan isi tulisan), Body (isi tulisan), dan Ending (Penutup tulisan). Maka dalam membuat tulisan feature, unsur tersebut harus lengkap agar feature yang dibuat menjadi feature yang layak untuk dibaca bahkan layak untuk dipublikasikan.

Kesalahan fatal yang menjadikan feature yang dibuat menjadi tidak layak dibaca adalah tidak meletakkan judul di atas tulisan. Padahal dalam setiap karya harus memiliki sebuah judul. Sesuai dengan pendapat (Sumadiria,2017:195) mengatakan bahwa judul feature menjadi identitas dan menjadi daya tarik pertama bagi pembaca. Selain itu, pada bagian Lead (Intro) rata-rata memiliki karakteristik Lead yang sama yaitu Lead deskriptif yang menggambarkan sebuah peristiwa dan beberapa lainnya menggunakan Lead bercerita yaitu memulai feature dengan menceritakan sebuah kisah.

Selanjutnya adalah pada bagian penggunaan kata dan kesesuaian ejaan diperoleh nilai rata-rata sebesar 68,31 yang berada pada kategori Cukup (C). Hal ini menandakan bahwa penggunaan ejaan dalam naskah feature masih rendah. Banyak ditemukan kesalahan-kesalahan dalam penulisan dinataranya kesalahan pengetikan seperti kurang huruf atau kelebihan huruf dalam suatu kata. Selain itu kesalahan dalam pengejaan kata. Hal ini disebabkan oleh beberapa faktor salah satunya adalah kurang teliti dalam mengetiknya atau bahkan tidak memeriksa kembali hasil tulisannya.

Selanjutnya, dalam pilihan kata hanya ditemukan beberapa kelompok kata diantaranya penggunaan kata ilmiah, kata populer, dan penggunaan idiom. Dari persentase yang diperoleh dapat disimpulkan bahwa, penguasaan diksi juga masih tergolong rendah. Mahasiswa hanya menggunakan bahasa yang standar yaitu bahasa yang pada umumnya digunakan dalam kehidupan sehari-hari. Padahal, sebenarnya mereka bisa menyampaikan feature mereka dengan menggunakan bahasa yang lebih imajinatif meskipun feature dibuat dengan berdasarkan pengalaman pribadi yang disampaikan ke dalam bentuk autobiografi mereka. Padahal pilihan kata dalam sebuah tulisan menentukan keberhasilan dari tulisan yang dibuat. Seperti pendapat keraf (2009: 23) yang mengatakan bahwa kekhilafan yang besar untuk menganggap bahwa persoalan pilihan kata adalah persoalan yang sederhana, persoalan yang tidak perlu dibicarakan atau dipelajari karena akan terjadi dengan sendirinya secara wajar pada setiap manusia.

Pada bagian unsur Human Interest, penulis menemukan fakta bahwa keseluruhan tulisan mengandung unsur Human Interest. Human Interest yang ada meliputi rasa tanggung jawab terhadap diri sendiri dan tanggung jawab terhadap orang lain. Setelah membaca feature yang ditulis oleh mahasiswa, penulis sebagai pembaca dalam hal ini ikut merasakan apa yang diceritakan oleh mahasisiwa ke dalam feature yang dibuatnya. Dengan membaca feature yang mengandung Human Interest, maka muncul rasa simpati dan empati bagi pembaca terhadap mahasiswa yang bersangkutan.

Perhatian semacam inilah yang dimaksud bahwa suatu peristiwa memiliki unsur Human Interest bagi pembaca meskipun tidak memiliki nilai berita seeprti aktualitas, kedekatan, keterkenalan, dan dampak. Sebenarnya, setiap perhatian pembaca adalah Human Interest, karena pembaca berbeda-beda penafsirannya dan daya tarik pribadi antara pembaca yang satu dengan yang lainnya. Maka berdasarkan hasil penelitian yang dilakukan penulis maka dapat disimpulkan bahwa kemampuan menulis feature 
Human Interest berbasis Kontekstual pada mahasiswa STKIP PGRI Lubuklinggau masih tergolong rendah.

\section{SIMPULAN}

Adapun simpulan yang didapat berdasarkan hasil penelitian adalah rendahnya kemampuan menulis feature Human Interest berbasis kontekstual pada mahasiswa STKIP PGRI Lubuklinggau

\section{REFERENSI}

Eneste, P. (2012). Penyuntingan Naskah. Jakarta: Gramedia.

Hikmat Kusumaningrat. (2016). Jurnalistik Teori dan Praktik. Bandung: PT Remaja Rosdakrya.

Keraf, G. (2009). Diksi dan Gaya Bahasa. Jakarta: PT Ikrar Mandiriabadi.

Romli, A. S. (2020). Jurnalistik Online Panduan Mengelola Media Online. Bandung: Nuansa Cendikia.

Yunus, S. (2012). Jurnalistik Terapan. Bogor: PT Ghalia Indonesia. 